\title{
Die Kaapse NG Kerk en die Groot Trek: 'n evaluering
}

\author{
Strauss, Piet \\ Universiteit van die Vrystaat \\ straussp@ufs.ac.za
}

\begin{abstract}
The Dutch Reformed Church in the Cape and the Great Trek: an evaluation.

The reaction of the Cape Synod of 1837 of the Dutch Reformed Church and the presbytery of Graaff-Reinet of 1838 and 1840 marked the official stance of the Dutch Reformed Church (DRC) on the Trek. Both were negative about the Trek because they saw it as a revolt against the British Government. These two assemblies were, however, influenced by the negative approach of the Trek in public opinion and willingness on their side to follow and bow to the government in this regard. The Trek after all, was an emigration. Since 1843 the approach of the DRC on the matter changed and the members of the DRC on the Trek were regarded as full church members who are not in a process of discipline because of their emigration.
\end{abstract}

\section{Keywords}

Emigration, Insecurity in society, Peaceful motives, Watershed in South African history, Interior of South Africa open for the influence of the West.

\section{Inleiding}

Die Groot Trek dui op die emigrasie van bykans 15000 mense in 18341840 uit veral die oostelike dele van die destydse (Britse) Kaapkolonie na die binneland van Suid-Afrika. "Groot" dui hier eerder op die impak as die omvang van die Trek (Thom 1965:75; Du Bruyn 1986:127). Die Groot Trek sou die binneland van Suid-Afrika - buite die Kaapkolonie - vir die Westerse leefwyse oopstel (Visagie 2012:148). Daar bestaan afdoende argumente om te aanvaar dat die kerk op die trekpad, vir sover dit hierdie emigrante of uitgewekenes of Voortrekkers - 'n term wat in die 1870's ontstaan - aangaan, die NGK was (Strauss 2011:264-277; Visagie 
2012:118)). Die Trekkers was lidmate van Nederduitse Gereformeerde Kerk (NGK)-gemeentes uit hoofsaaklik die Oos-Kaap en die Ring van GraaffReinet: Graaff-Reinet, Uitenhage, Cradock, Beaufort-Wes, Somerset-Oos, Colesberg, Balfour, Glen Lynden en Albanie (Dreyer 1929:27; Van der Watt 1977:15).

In daardie stadium is die name Nederduitse Gereformeerde Kerk (NGK) en Nederduitse Hervormde Kerk (NHK) as wisselterme gebruik. Die NGK-sinode van 1842 besluit egter dat die naam voortaan die Nederduitse Gereformeerde Kerk (van Suid-Afrika) ${ }^{1}$ sal wees (NGK in ZA 1858:197198). Daarom volstaan hierdie stuk met hierdie naam.

Volgens Van der Watt was die "grootskaalse eksodus" van sommige van hulle getrouste lidmate vir die genoemde gemeentes 'n groot verlies. Die impak van die landsverhuising én die publieke aandag wat dit getrek het, het die saak nie net op die agenda van die Ring van Graaff-Reinet van 1838 en 1840 en die Kaapse NGK-sinode van 1837 geplaas nie. Regeringslui in die Kolonie sou ook hierop reageer (Van der Watt 1977:5-6, 15).

Die reaksie van die ring en die sinode het op twee sake gekonsentreer: die redes of motiewe vir die Trek en die bestemming van die Trek.

Die redes van segslui vir die Trek soos Karl Trichardt, Piet Retief en Anna Steenkamp, 'n broerskind van Retief, kan soos volg opgesom word: 'n gebrek aan grond, kapitaal en arbeid in die Kolonie, 'n opkomende nasionalisme en 'n behoefte aan selfregering by die Trekkers, hulle weerstand teen gelykstelling met die gekleurdes in die Kolonie en die onveiligheid wat ongekontroleerde rondlopery onder laasgenoemde saam met die oosgrensoorloë teen die Xhosas vir hulle geskep het (Giliomee 2003:144153). Onder die Gekleurdes sou van die eertydse slawe van die emigrante en die nomadiese Khoi-Khoi (Khoen-khoen) tel (Thom 1965:50-74; Van der Watt 1977:3-5; Visagie 2012:122).

1 Die agtervoegsel "van Zuid-Afrika" dui in 1842 op die Kaapkolonie. Hierdie begrip werk verwarrend in op Nederlandse gereformeerdes in die 1950's wat verstaan dat dit die NGK in die hele Suid-Afrika aandui, Strauss 1983:67. Die eerste Algemene Sinode van die hele NGK besluit in 1962 dat die naam van hierdie kerkverband die "Nederduitse Gereformeerde Kerk" sonder enige geografiese agtervoegsel of staatkundige grens sal wees. Die kerk se grense word immers deur die geloof en nie staatsgrense nie, bepaal. Staatsgrense vir die NGK was 'n ongelukkige oorblyfsel van die bekende (berugte) Loedolffsaak van 1862, Van der Watt 1973:164. 
Sowel die Kaapse Sinode van 1837 as die Ring van Graaff-Reinet van 1838 en 1840 sou egter aan hierdie redes verbygaan. 'n Feit wat die indruk versterk dat hulle uit voeling was met Trekkerlidmate en met 'n vooringenomendheid na die uittog gekyk het. Kerklik uitgedruk: die herderlike brief van die sinode en die hantering van die Trekkerlidmate deur die ring het geïmpliseer dat die uittog sonde is en 'n opstand teen die Britse Regering aan die Kaap. 'n Daad wat, op die klank af, kerklik beskou 'n tugwaardige sonde is (Bouwman 1985:620-621).

'n Evaluering van die optrede deur hierdie sinode en ring moet die hele Trek met sy motiewe en die staatkundige konteks in ag neem om tot gegronde gevolgtrekkings te kom. Wat was die houding van die Kaapse NGK teenoor die Groot Trek en hoe moet dit geëvalueer word? Was hierdie optrede kerklik verantwoord en gebaseer op die feitlikhede van die Groot Trek? Is Trekkerlidmate kerklik verantwoord hanteer? Was die Trek 'n opstand of 'n emigrasie en was die Trekkers skuldig aan alles waarvan die Kaapse Sinode hulle beskuldig het?

Die houding van die buitengewone Kaapse Sinode van die NGK van 1837 (NGK van ZA 1858:112) was bepalend vir die optrede van die Ring van Graaff-Reinet van 1838 en 1840.

\section{Die Kaapse Sinode van 1837 en die Groot Trek}

\subsection{Die klimaat waarin die sinode vergader het.}

In die beginjare van die Groot Trek het voornemende Trekkers hulle verkenning en voorbereiding in stilte gedoen. Volgens C Hattingh, 'n ooggetuie, is hierdie stilte gehandhaaf omdat hulle bang was om deur die Britse Regering "voor rebellen gehouden te worden" (Preller 1920:115116). Daar was ook 'n persepsie by die Trekkers dat die regering hulle kan verbied om die grense van die Kolonie oor te steek (Van der Watt 1977:5).

Om beter weiding aan hulle vee te voorsien en moontlike vyandelikhede van die regering die hoof te bied, het die Maritz-trek in 1836 aanvanklik in kleiner groepe getrek. Hulle het op Thaba Nchu besluit as 'n bymekaarkomplek nadat hulle die Kolonie verlaat het (Thom 1965:80). 
Die houding van die koloniale regering aan die Kaap teenoor die Trek is belangrik vir ons tema omdat hierdie regering - soos in die dae van die Verenigde-Oos-Indiese Kompanjie - wetlik bepalende seggenskap in die sake van die NGK aan die Kaap gehad het. Nie alleen het die regering deur middel van die goewerneur die predikante aangestel en besoldig nie, maar die besluite van kerkvergaderings moes ook aan hom vir bekragtiging voorgelê word (Dreyer 1932:5; Van der Watt 1973:27). Die bekende Ordonnansie 7 van 1843 met die titel The Separation of Church and State Petition wou hieraan 'n einde maak. Die NGK is hierdeur egter aan die besonderhede van 'n staatswet vir sy vryheid en selfstandigheid gekoppel. 'n Saak wat van staatsweë eerder deur die grondwetlike erkenning van die vryheid van godsdiens in die algemeen sonder 'n wet met bindende bepalings vir 'n bepaalde kerk, gereël kon word (Van der Watt 1973:32, 39).

Die versigtigheid van die emigrante vir die Britse regering was aanvanklik ongegrond. Die regering wou nie met sy staatsapparaat teen die Trekkers optree nie. Later het die weerstand van die regering teen die emigrasie sterker vorme aangeneem.

Sowel goewerneur Benjamin D'Urban as die luitenant-goewerneur van die Oostelike provinsie, sir Andries Stockenström, het in die beginjare (18341836) van die Trek verklaar dat 'n regeringsverbod op emigrasie drakonies en onwenslik sou wees. Dit het nie beteken dat hulle die Trek goedkeur nie. Volgens D’Urban kon die Trek die Kaapkolonie ruïneer. Die emigrante moes deur oorreding oorgehaal word om in die Kolonie te bly. Later het Stockenström by D'Urban se opvolger, sir George Napier, aangedring dat die emigrante vervolg word (Thom 1965; Van der Watt 1977:6). Op 28 April 1838 rig Napier hom tot die NGK-predikante met die versoek dat hulle "deze rasernij van emigratie" help stuit (Van der Watt 1977:6). Hierna vaardig hy 'n "verordening" uit dat die emigrante voor 1 Januarie 1839 in die Kolonie terug moes wees. Op hulle terugkeer sou amnestie, skadeloosstelling en aandag aan hulle griewe volg. Die regering sowel as die Trekkers het egter geen gevolg aan hierdie maatreël gegee nie (Thom 1965:90-91).

Die houding van die Kaapse regering was duidelik: hulle keur die Trek nie goed nie. Hierdie anti-trekhouding van die regering was ook teen November 1837 by die Kaapse Sinode bekend (Van der Watt 1977:6). 
Die negatiewe klimaat in die Kolonie teenoor die Trek is gevoed deur die menings van indiwiduele NGK-predikante. Hoewel hulle menings nie noodwendig voor die sinode van 1837 opgeteken is nie, sou latere dokumente hulle afkeur aan die Trek verwoord. Menings wat hulle waarskynlik reeds voor die sinode toegedaan was. 'n Uitsondering is $\mathrm{dr}$ William Robertson van Swellendam wat reeds op 13 Maart 1836 in 'n brief van onrealistiese verwagtings oor die binneland as 'n motief vir die uittog by voornemende emigrante melding makk. Hulle hoofrede is volgens hom die geldelike verliese wat hulle as gevolg van die vrystelling van die slawe gely het (brief afgedruk in Dreyer 1929:7).

In die godsdiensverslag van sy gemeente, Somerset-Oos, in 1838 noem ds G Morgan die Trek 'n "dwaling" waarvoor die Here die land moet "behoede". In 'n preek in Maart 1838 vergelyk ds Taylor van Cradock die Trek met die vlug van Jona: die Trekkers vlug vir hulle roeping van die Here in die Kolonie. In gesprekke bestempel dr Robertson (die skriba van die sinode van 1837, NGK van ZA 1858:183) van Swellendam die motiewe vir die Trek as "foolish reasons" (Van der Watt 1977:11). Bekend is ook die pogings van ds A Murray (senior) om trekleier Gerrit Maritz en sy vrou van die Trek te laat afsien. Sy raad ontlok harde woorde van Maritz en hy word die Maritzhuis belet (Thom 1965:74).

Gelet op die sosiale posisie van hulle predikante onder NGK-lidmate, het hulle dominees 'n belangrike deel van die publieke opinie gevorm waarin die voornemende Trekkers beweeg het. Boonop was die houding van die koloniale regering wat die emigrante deur wetgewing kon dwing, 'n faktor om mee rekening te hou. Onder hierdie omstandighede was die negatiewe houding van die Sinode van 1837 teenoor die uittog geen verrassing nie.

Die houding van die Sinode is vervat in 'n herderlike brief wat na gemeentes gestuur is. 'n Kommissie onder leiding van ds TJ Herold van Stellenbosch is op die derde sittingsdag van die sinode vir die "vervaardiging" hiervan benoem (NGK in ZA 1858:121). Die sinode sou 30 sittingsdae in beslag neem (NGK in ZA 1858:183) en het die brief op 20 November 1837 vir versending goedgekeur. 


\subsection{Die houding van die sinode teenoor die uittog}

Die herderlike brief praat sterk afkeurend van die uittog met geen teken van 'n pastorale begrip vir die Trekkers nie.

Die uittog "van zoo vele Ledematen der Hervormde Kerke" stem die sinode tot droefheid omdat hulle sonder leiers soos 'n Moses en 'n Aaron uittrek met geen belofte van 'n Kanaän wat op hulle wag nie (brief afgedruk in Dreyer 1929:3).

Die sinode hou elkeen van hierdie lidmate "verantwoordelyk voor hun gedrag" en herinner hulle aan hulle vrywillige belydenis van geloof en die doop van hulle kinders wat 'n "dure verplichting" op hulle geplaas het. Die Trek is nie 'n "wenk" van die "Goddelyke voorzienigheid" nie. Die Trekkers moet hulle kruis in die Kolonie opneem en Christus volg. Hulle moet hulle onderwerp aan diegene wat deur God oor hulle gestel is. Ook die Kaapse owerhede is dienaars van God wat die swaard met geregtigheid en beskeie moet dra. Dit is laakbaar om van die owerheid te verwag dat hy hom skik na "onzen zin en belangen". Hy moet vir die algemene welsyn en toekomstige welvaart van die land werk. Wat tans vir ons na kwaad lyk, word dikwels "tot eenen zegen; wat ons tydelyke schade veroorzaakt, een middel tot bevordering van ons eeuwig geluk" (hele brief in Dreyer 1929:3-4²).

Hierdie brief word deur ds Herold aan die sinode vir goedkeuring voorgehou en met 'n meerderheid van stemme aanvaar. Vier predikante is daarteen ${ }^{3}$. Hulle lê hulle redes aan die vergadering voor. Volgens ds GWA van der Lingen van die Paarl kom die omstandighede wat die brief skets nie ooreen met die "omstandigheden daar wij in leven." Ds JC le F Moorrees van Swartland ken die "zaak van de uitgewekene Boeren" nie goed genoeg om “ja” te stem nie. Ds HA Moorrees van Tulbagh kan dieselfde Boere "niet zoo dadelijk ... veroordeelen”. Vir ds Morgan van Somerset-Oos handel die brief oor 'n politieke en nie 'n kerklike saak nie. Daarom stem hy daarteen (opmerkings afgedruk in Dreyer 1929:5).

2 Dreyer beweer dat van die Kaapse NGK-predikante "eerlik daarvan oortuig" was dat die steeds beter in die Kolonie onder die Britse vlag was as in die "woeste wildernis" van die Suid-Afrikaanse binneland, 1932:6.

3 Dreyer vermeld dat die konsepbrief of "De Herderlijke Herinneringen en Toespraken" "heftige teenstand" vanaf die sinodevloer ontlok het, 1932:1,3. 
Die redes vir hierdie houding van die Kaapse Sinode van 1837 is sedertdien dikwels bespreek (Dreyer 1929:2; Van der Watt 1977:18-20; Strauss 2015:2628). Tog bly dit vir ons tema van groot belang.

Die sinode het bestaan uit elf dominees van Skotse oorsprong, nege Afrikaanse of Afrikanerpredikante, een dominee van Nederlandse en een van Duitse afkoms. Daarby was daar negentien Afrikaanse ouderlinge ${ }^{4}$. Die bewering word gemaak dat die oorwig Skotse predikante die sinode verhoed het om die motiewe van die uittog van die - soos hulle toe al genoem is (Strauss 2015:5) - Afrikanerboere te verstaan. Die stemming oor die herderlike brief sou dus "etnies"-bepaald gewees het (Dreyer 1929:1-2).

Hierdie etniese verklaring vir die inhoud van die herderlike brief gaan nie op nie. Immers, van die 41 sinodelede kan 28 - 9 predikante en 19 ouderlinge - waarskynlik deurgaan as Afrikaners. Daarby was minstens een van die vier predikante wat teen die brief gestem het, ds Morgan, 'n Skot. Boonop het twee Skotse predikante, di Reid van Colesberg en Taylor van Cradock, die Ring van Graaff-Reinet in 1840 versoek om sanksie aan die pastorale besoeke wat hulle aan die Trekkers wou bring, te verleen (Van der Watt 1977:17-18). Die gemeentes op die oosgrens waaruit die emigrante gekom het, is almal deur Skotse predikante bedien (Dreyer 1929:1-3; 1932:5). Gedagtig daaraan dat die Skotte erns gemaak het met die taal en omstandighede van hulle lidmate, is dit onwaarskynlik dat die motiewe vir die uittog aan hulle heeltemal onbekend was. Of hulle daarmee saamgestem het, is 'n ander saak.

In hierdie verband is dit interessant dat ds Taylor in 1840 deur Boereemigrante "far beyond the boundary" onder AH Potgieter versoek word om of hulle permanente dominee te word of om hulle te besoek en alle leraarspligte te vervul. 'n Versoek wat deur die goewerneur toegestaan word. By die Ring van Graaff-Reinet is Taylor egter nie so gelukkig nie. Hier kry hy toestemming om die besoek af te lê, maar verbied om die sakramente te bedien (briewe in Dreyer 1929:29-33). 'n Besluit wat op "sydelingse sensuur" (term by Dreyer 1932:7) neerkom omdat die sinode van 1837 die uittog in 'n kwade lig beskou en alle Trekkers sonder aansiens des persoons

4 Die naam en begrip “Afrikaner” was op hierdie stadium al in gebruik, Giliomee 2003:22; Grobler 2007:19,25. 
veroordeel het sonder om hulle kant van die saak te ondersoek. Daarmee het die sinode die audi alteram partem-reël in kerklike tugsake wat tot berou by indiwiduele gelowiges moet lei, verontagsaam (Sadler 1979:186; NGK 2013:16-22).

\subsection{Dienstigheid aan die owerheid}

Dit wil voorkom asof die besluit van die sinode van 1837 mede-beïnvloed is deur'n kerklike trou of dienstigheid aan die Britse regering. 'n Dienstigheid wat moontlik uit 'n strakke, enge verstaan van die vyfde gebod naamlik gehoorsaamheid aan gesag spruit én 'n houvas van die staat op die NGK by implikasie erken. In hierdie omstandighede het die sinode die roeping van die NGK-gelowige tot die Kolonie beperk en - by implikasie - enige verlating van die land as roepingsontduiking beskou: hetsy deur emigrasie of die ekonomiesgedrewe trekboere wat sedert 1820 oor die Grootrivier is. Ds Taylor se vergelyking van die uittog met die vlug van Jona illustreer hierdie houding by NGK-predikante.

Dit wil voorkom asof die sinode in sy dienstigheid verhinder is om te begryp dat die emigrasie nie 'n opstand is nie, al is ontevredenheid oor die owerheid een van die redes daarvoor. Ontevredenheid oor die owerheid lei nie noodwendig tot ongehoorsaamheid en dus 'n oortreding van die vyfde gebod nie. Jy kan met die owerheid verskil sonder om sy gesag te bevraagteken of sy juridiese rol in algemene landsbelang te ontken. Vanuit sy gewilligheid (en versigtigheid) om die owerheid gunstig te stem, het die sinode hierdie onderskeiding nie getrek nie.

Tydens 'n "amptelike" besoek aan die emigrante in Natal in 1843 deur die aktuarius van die Kaapse Sinode, dr Abraham Faure, stel hy die saak reg as hy in sy verslag aan die Kaapse goewerneur wat sy besoek finansier (Dreyer 1932:29), na die boere verwys as emigrante. By hom is daar nie sprake van 'n opstand - in staats- of kerklike terme nie (verslag in Dreyer 1929:5867). Hierdie houding van Faure word ondersteun deur die populêre naam "emigrante-boere" wat destyds aan die orde van die dag in die Kolonie was. 'n Naam waarby selfs Napier inval as hy in 1838 praat van "deze rasernij van Emigratie" (Van der Watt 1977:6). Die emigrante was nie in opstand nie en het geen aksie teen die Britse owerheid aan die Kaap beoog nie ${ }^{5}$. Inteendeel,

5 Moderne historici hou hulle steeds met die vraag na die Groot Trek as 'n rebellie of 'n opstand besig. Giliomee praat van 'n ordelike, vreedsame "mass rebellion" teen 
hulle wou eenvoudig oor die grense van die Kolonie trek en 'n nuwe tuiste vind. Hulle wou in 'n land gaan woon waaroor Brittanje nie regeer nie en waarin niemand anders hulle tuiste het nie. Daarom het Trekkerleier Retief met die Zoeloekoning Dingaan onderhandel om 'n gedeelte van die teenswoordige KwaZulu-Natal (Thom 1965:208).

Die dienstigheid van die sinode van 1837 aan die Britse regering word ook geillustreer deur sy gelukwensing aan koningin Victoria met haar troonsbestyging in 1837. Dit gaan hier nie om die gelukwensing nie - dit is vermeldingswaardig - maar die boodskap wat saam gestuur is. Die sinode sou 'n adres aan haar stuur "en onze Hervormde Kerk aan Hare Majesteits koninklijke gunst aanbevelende ...” (NGK in ZA 1858:122). Met hierdie woorde buig die NGK laag voor die jong Britse koningin. Van 'n kerklike profeties-kritiese afstand is hier nie sprake nie, al sou die woorde op die gebruiklike, byna betekenislose lofuitinge dui.

In sy weerstand teen die herderlike brief van die sinode van 1837 toon ds GWA van der Lingen dat hy die verstaanskloof tussen die sinode en die Trekkers raaksien. Daarom voel hy dat die besluit van die sinode die omstandighede van die Trek verkeerd verwoord. Dit verbaas dus nie dat Andries Pretorius as 'n aangewese leier van die uitgewekenes ds Van der Lingen op 8 Junie 1838 in 'n brief vanaf sy plaas naby Graaff-Reinet versoek om 'n leraar vir die emigrante te stuur nie. Hy doen dit omdat Van der Lingen "sonder vooroordeel" in die "zwerfvende Colonisten" belangstel en "een waare Afrekaan ben” (brief in Dreyer 1929:13-14). Van der Lingen sou simpatiek reageer (Liebenberg 1977:28).

Pretorius wat op die punt is om sy huis in die Sneeuberg te verlaat vir hulp aan die beleerde Trekkers in Natal, gee in sy bewoording blyke van 'n aantal indrukke. In die eerste plek ervaar hy die druk van openbare opinies - soos die van die Kaapse Sinode - teen die uittog. Opinies waarin hy meen om brute vooroordeel waar te neem. In die tweede plek laat blyk hy onsekerheid oor die bestemming van die Trek. Die terme "zwerfvende Colonisten" stem ooreen met die uitdrukking "de in de woestijn bijeenverzamelde Gereformeerde Kerkgemeente" wat die goewerneur van die Trekkers, Piet Retief, in 'n bykomende eed by sy ampsaanvaarding in

'n ineenstorting van bestaansveiligheid (Giliomee 2003: 144). Visagie noem dit 'n "rebellie", hoewel vreedsaam van aard (Visagie 2012:118). Beide vermy egter die kwessie van 'n geweldadige rebellie met terme wat ook as 'n emigrasie sou kon deurgaan. 
sy beskerming neem. 'n Eed wat hy naby die latere Winburg op 11 Junie 1837 in die teenwoordigheid van eerwaarde (ds) Erasmus Smit voor die emigrante aflê (Preller 1920:107). Swerwende én in die woestyn dui albei op 'n onsekerheid oor die toekoms en 'n gebrek aan 'n duidelike bestemming vir die Trek. In die derde plek noem Pretorius ds Van der Lingen - soos die Trekkers hulleself - 'n ware Afrikaner. Van der Lingen sou as 'n ware Afrikaner homself immers kon terugvind in die groeiende nasionalisme en selfregeringsideale van die mense van die Uittog.

\subsection{Die Kaapse Sinode en die Groot Trek: 'n evaluering}

In hierdie stadium is dit reeds duidelik dat die Kaapse Sinode van 1837 aan die selferkende redes vir die Groot Trek verbygegaan het en geen kerklik-pastorale aanvoeling vir hierdie ingrypende stap van sommige lidmate geopenbaar het nie. Gedagtig aan die feit dat die NGK as kerk vir die uitgewekenes belangrik was, moes die houding van die sinode vir hulle - by al hulle ander probleme met die lewe in die Kolonie - 'n verdere terugslag gewees het. Daarom dat Andries Pretorius in sy brief van Junie 1838 aan ds Van der Lingen na die weerstand van laasgenoemde teen die herderlike brief van die sinode vir hom aan "ons" kant teenoor die sinode aan die "ander" kant geplaas het.

Daarmee het Pretorius by implikasie aangetoon dat die sinode vir die uitgewekenes in hulle stryd om 'n sinvolle oorlewing of bestaan irrelevant geword het.

Dat die NGK vir die mense van die uittog belangrik was, word deur die gebruike van hulle kerkwees op die trekpad gestaaf. Hierdie gevolgtrekking blyk uit die Trekkers se gebruik van die naam NGK, hulle gehegtheid aan die belydenisskrifte ${ }^{6}$ en kerkorde van die Kaapse NGK, hulle herhaalde versoeke om 'n vaste leraar uit die verband van die Kaapse Sinode en hulle gebruike in eredienste, by die verkiesing van kerkraadslede en in die kerk se verhouding tot die Trekkerowerheid. Hierdie owerheid is met die Vetriviergrondwetreëlings in Mei-Junie 1837 naby die latere Winburg vasgestel (De Jongh 1977:134). Pretorius het na die Slag van Bloedrivier op

6 In sy aanvullende eed as goewerneur van die Trekkers belowe Piet Retief op 11 Junie 1837 by die Vetrivier naby die latere Winburg om die NGK en sy belydenisskrifte te beskerm, Strauss 2001:817. 
16 Desember 1838 op 23 Desember aan die Voortrekkervolksraad in Natal verslag gelewer (Strauss 2001:821). Hiernaas het Trekkerlidmate gereeld na die hulle ou gemeentes in die Kolonie teruggekeer om aanspraak te maak op hulle lidmaatsvoorregte. Vanaf 1840 tot 1845 word 687 kinders byvoorbeeld in Colesberg se doopboek as "over de Grenze” en 407 huwelike in die register as "buiten de Grenze” aangeteken (Van der Watt 1977:20; vgl Strauss 2011:268-273).

Op die sinode se verwarring van emigrasie met 'n opstand wat teen die vyfde gebod ingaan, is ook gewys. Die sinode het 'n gebrek aan 'n gereformeerd-kerklike insig getoon deur die implikasies van hierdie verwarring vir die hantering en moontlike tugtiging van die betrokke lidmate nie te verreken nie. Lidmate is aan 'n oortreding van die vyfde gebod skuldig bevind sonder dat die redes om te trek van indiwidue of selfs die groep as geheel deur hulle eie kerkrade onder wie se toesig hulle geval het, aangehoor en verreken is. Die vasstelling van 'n oortreding of 'n sonde in die kerklike tugproses is, soos berou en bekering as die doel van die tug, iets persoonliks of indiwidueels. Grondige kerklike tug is pastoral-soekend omdat dit ook gaan om die behoud van die sondaar (Bouwman 1985:620621; NGK 2013:16).

Sommige ander formulerings in die herderlike brief van 1837 wek ook vrae.

Die sinode se sogenaamde droefheid omdat die Trekkers sonder 'n belofte aan 'n land soos Kanaän en sonder charismatiese leiers soos Moses en Aaron trek, val vreemd op omdat beide kwessies teen November 1837 nog nie volledig hanteer en afgeloop is nie. Dit is 'n vraag hoeveel sinodelede bekend was met die indiwiduele Voortrekkerleiers of oor genoegsame inligting oor die betrokke persone beskik het om sulke krasse waarnemings te maak. Miskien het die sinode gewerk met die persepsie dat min emigranteleiers tot op daardie stadium hulleself in die openbare lewe van die Kolonie onderskei het. 'n Terugblik op die impak van die Groot Trek op die hele Suid-Afrika, toon egter dat hierdie leiers voorgeloop het in 'n proses wat die binneland van Suid-Afrika radikaal sou verander (Du Bruyn 1986:127)7.

7 Dreyer noem die Groot Trek "een van die mees betekenisvolle gebeurtenisse in die geskiedenis van Suid-Afrika” (Dreyer 1932:1). Volgens Visagie is die Groot Trek "een van die belangrikste verskynsels in die Afrikaners se geskiedenis ... 'n beslissende keerpunt" (Visagie 2012:149). 
Daarby is die summiere vermelding of aanname van die moontlikheid dat die emigrante nie hulle lidmaats- of doopouerbeloftes op die trekpad sal nakom nie, 'n verdere illustrasie van die sinode se onbekendheid met die Trekkers. Laasgenoemde sou bekend word vir hulle godsdiens (Boekevat) en handhawing van die gereformeerd-kerklike belydenisskrifte. 'n Klem wat kategese sou insluit (De Jongh 1977:160). In sy godsdiensverslag aan die ring rapporteer die gemeente Uitenhage in 1839 so oor die emigrante: "vele van hun waren onder de trouwste Kerk en Avondmaalgangers te bevinden

..." (Van der Watt 1977:15) Op hierdie punt oordeel Dreyer dat die sinode, behalwe vir sy dienstigheid aan die Kaapse regering, tog ook bekommerd was dat die "Voortrekkers" geestelik sou veragter. Daarom die verwysing na lidmaatsbeloftes (Dreyer 1932:4).

Op die eensydigheid en engheid om die opneem van die kruis van Christus in 1837 tot die Kolonie te beperk, is reeds gewys. Hiervolgens sou die opneem van die kruis op enige ander plek eenvoudig op ongehoorsaamheid aan God of sonde neerkom. Net so eng en onkerklik kil is die slotopmerking van die herderlike brief. Dat die emigrante se tydelike "schade" hulle ewige geluk sou bevoordeel, is 'n skrale, byna onbarmhartige poging om te troos. Hierdie opmerking klink boonop soos die piëtistiese "pie in the sky when you die".

\section{Die Ring van Graaff-Reinet en die Groot Trek}

Van der Watt kom tot die slotsom dat die Ring van Graaff-Reinet in 1840 sy "ware kleur" teenoor die Trekkers gewys het (Van der Watt 1977:16).

In 1838 word die Ring gekonfronteer met twee vrae uit Colesberg. Hoe moet diegene hanteer word wat die Kolonie verlaat het, reeds meer as 'n jaar buite die grense woon en dan terugkom om hulle lidmaatsregte op te eis? En: hoe moet diegene hanteer word wat deur armoede of finansiële nood buite die grense van die gemeente woon? Eersgenoemde is emigranteBoere en laasgenoemde Trekboere. Die antwoord van die ring is vaag en ontwykend: hierdie mense moet met die grootste versigtigheid en "Christelijke toegevendheid" hanteer word: alles volgens die "bestaande wetten en gebruiken der Kerk" (afgedruk in Dreyer 1929:28). 
In 1840 word die ring voor twee versoeke geplaas. Ds Reid van Colesberg én ds Taylor van Cradock vra verlof om die emigrante oorkant die Grootrivier te besoek. Ds Reid wil "alleenlijk" die evangelie onder hulle verkondig, terwyl ds Taylor 'n besoek van 3 maande beplan waartydens hy "al mijn werk als Leraar naar de omstandigheden zoo ver als ik kan" verrig. Hy toon ook 'n skriftelike toestemming van die Kaapse goewerneur om "ministerial duties, such as the administration of the Sacraments ..." vir 3 maande onder die emigrante uit te voer. Verder maak hy voorstelle oor hoe die werk in sy gemeente gedurende sy afwesigheid gedoen kan word (afgedruk in Dreyer 1929:29-31).

Wat ds Reid betref, het die ring geen beswaar teen sy voorgenome besoek met die doel om "alleenlijk het Evangelie" onder die emigrante te verkondig nie (afgedruk in Dreyer 1929:29). Dit is egter nie duidelik of hierdie besoek ooit plaasgevind het nie. Op ds Taylor se versoek antwoord die ring dat hy die verlof deur die goewerneur verleen, nie "kan" teenstaan nie. Ds Taylor moet die vergadering egter verseker dat hy "aldaar de Sacramenten niet zal uitdeelen nog lidmaten aannemen ...” (afgedruk in Dreyer 1929:32).

Van der Watt se verwysing na sy ware kleure dui moontlik op 'n paar tendense by die ring.

In die eerste plek is die ring, soos die sinode van 1837, gekant teen die Trek. Daarby interpreteer die ring die sinodebesluit van 1837 skynbaar so dat 'n opstand tugwaardig is en dat die opstandelinge die sakramente onder sensuur as 'n tugmaatreël ontsê moet word. Die ring trek dus die logiese kerklike konklusie van die sinodebesluit. Tensy hy hierdie "sydelingse sensuur" (Dreyer se tipering van die saak, 1932:7) wat nie'n erkende kerklike gebruik is nie, as sensuur sonder 'n ondersoek op sy eie beoordeling van die uittog grond. So 'n beoordeling word egter nie gevind nie.

Die tendens is nietemin duidelik: hier gaan dit om sensuur sonder om die ander kant van die saak te hoor en lidmate in dié proses indiwidueel en pastoraal te bearbei. Boonop wil die ring lidmate van die sakramente onthou terwyl hulle onder die toesig van hulle eie kerkrade val. Vergaderings van die NGK was hier dus skuldig aan die verontagsaming van hulle eie kerkordelike prosedures. 'n Fout wat die Kaapse Sinode met die bekende leerkwessie in die NGK ook in 1862 gemaak het (Strauss 2015: 53). 
Ds Taylor het ingeval by die ringsbesluit, maar na alle waarskynlikheid tog van die emigrantekinders gedoop. Die doopregister van Cradock vermeld in die tyd die doop van kinders "over de Grenze" (Van der Watt 1977:17).

Mettertyd sou daar in die amptelike houding van die Kaapse NGK teenoor die Groot Trek, soos vergestalt in hierdie optrede van die Sinode van 1837 en die Ring van Graaff-Reinet van 1838 en 1840 'n verandering kom (Van der Watt 1877:49-57). 'n Verandering wat nie in die herroeping van al hierdie besluite lể nie, maar in nuwe situasies en besluite en 'n ander benadering. 'n Verandering wat die tot die spreekwoordelike "normalisering" van die verhoudinge tussen die Kaapse NGK en NGK-gemeentes in die binneland sou lei.

\section{Die NG Kerk en die afloop van die Trek}

Van der Watt oordeel dat die besoek van dr A Faure, die aktuarius van die Kaapse Sinode, in 1843 aan Natal saamval met die verandering in die houding van die Kaapse Kerk teenoor die Groot Trek. Hy skryf dit aan meer as een faktor toe.

In die eerste plek het Ordonnansie 7 van 1843 die NGK "tot 'n groot mate" vry gemaak om in die geestelike behoeftes van sy lidmate buite die grense van die Kolonie te voorsien. Die NGK was ook daarvan oortuig dat die emigrasie 'n gevestigde gemeenskap buite die Kolonie tot gevolg gehad het. Hierdie waarneming is tydens die besoek aan Natal deur dr Faure bevestig. Een gevolg hiervan was 'n meer georganiseerde kerklike lewe. Boonop het dr Faure die NGK-lidmate waar hy ontvang is, ten volle bedien. Sy besoek was amptelik: die goewerneur én die NGK is in die saak geken. Teen hierdie agtergrond het Faure die kwessie van die Trek as 'n opstand finaal gekelder met sy deurgaanse verwysing na die Trekkers as emigrante (Verbatimverslag "Afvaardiging van ds A Faure na Natal" in Dreyer 1929:40-73; Van der Watt 1977:49-50).

In die tweede plek is daar predikantekommissies na die gebied oorkant die Grootrivier gestuur om die uitgewekenes ten volle met Woord en sakrament te bedien, gemeentes te stig en kerkraadslede te laat verkies.

8 Die Ring van Graaff-Reinet het wel sy besluit oor ds Taylor in 1840 waardeur die dominee verbied is om die sakramente te bedien, herroep Van der Watt 1977:52. 
Die Ring van Graaff-Reinet stuur ds WA Krige van Victoria in 1846. Die Kaapse Sinode stuur drie deputasies: di A Murray van Graaff-Reinet en PK Albertyn van Prins Albert in 1847-1848, dr PE Faure van Wynberg en W Robertson van Swellendam in 1848-1849 en di A Murray van Bloemfontein en JH Neethling van Prins Albert in 1851-1852. Hierdie deputasies hanteer die Trekkers soos ongesensureerde NGK-lidmate buite die grense van bestaande gemeentes. Van der Watt oordeel dat hierdie deputasies die Herderlike Brief van die sinode van 1837 genegeer en oneffektief gemaak het (Van der Watt 1977:51).

Nuwe gemeentes moes gestig word. Gemeentes wat natuurlikerwys in die verband van die Kaapse NGK opgeneem word (Dreyer 1929:74-184; Van der Watt 1977:49-57). Met die ontstaan van die Nederduitsch Hervormde Kerk in 1853 en die Gereformeerde Kerk in Suid-Afrika in 1859, albei in Transvaal (oor die Vaal), is hierdie patroon egter verbreek (Strauss 2015:3033).

Wat wel waar is, is dat die verhoudings met die nuwe NGK-gemeentes in die latere Vrystaat en in Natal teen 1843 genormaliseer is. Hierdie gemeentes was deel van die Kaapse Sinode tot met die Loedolffsaak in 1862 (Van der Watt 1973:107). Daarmee is die effek van die sinodebesluit van 1837 en die besluite van die Ring van Graaff-Reinet in 1838 en 1840 finaal gedoof.

\section{Die Kaapse NG Kerk en die Groot Trek: slot}

Dit gebeur dikwels in die bestaan van kerkvergaderings dat omstrede besluite nie letterlik herroep word nie, maar deur latere optrede en ontwikkelinge van dieselfde kerk genegeer word. Dat verdere ontwikkelings sulke besluite eenvoudig vergete agterlaat. So iets het in die Kaapse NGK met die sinodebesluit van 1837 oor die Groot Trek gebeur.

In die anti-emigrasie openbare denkklimaat van destyds in die Kolonie en gedienstig aan die Britse regering, het die sinode van 1837 ontevredenheid met die owerheid en emigrasie met opstand teen die owerheid verwar. Die feit dat so 'n opstand in stryd met die vyfde gebod is, het aan die optrede van die emigrante die kleur van 'n tugwaardige sonde verleen. Tugwaardige sondes van lidmate moet egter deur hulle eie kerkrade hanteer word. Dit het nie gebeur nie. Die Ring van Graaff-Reinet het predikante uit sy geledere wat die emigrante wou gaan bedien verbied om die sakramente ook aan 
hulle te bedien. Hierdie verbod het op "sydelingse" sensuur neergekom terwyl daar geen tugondersoek was en hulle kerkrade ook nie betrokke was nie. In die latere kontak van Kaapse NGK-predikante met die emigrante is die sinodebesluit van 1837 genegeer. So het hierdie besluit sy geldigheid stilweg verloor.

Ten spyte van die sinodebesluit van 1837 het die NGK in verskillende dele van Suider-Afrika in 1962 verenig in een algemene sinodale verband. Hier was die besluit van 1837 ook nie in oorweging nie.

Terugskouend kan dit gesê word dat die Kaapse Sinode van 1837 nie 'n demper of effektiewe verbod op die Groot Trek kon plaas nie en daarmee nie die ontwikkelingsmoontlikhede wat dit in Suid-Afrika geskep het, kon verydel nie.

\section{Bibliografie}

Bouwman, H 1985. Gereformeerd Kerkrecht II. Kampen: de Groot Goudriaan.

Dreyer, A 1929. Die Kaapse Kerk en die Groot Trek. Amptelike en ander stukke versamel, van aantekeninge voorsien en uitgegee. Kaapstad: Van de Sandt.

Dreyer, A 1932. Kerklike uitsprake oor die Groot Trek. Kaapstad: Van de Sandt, De Villiers en kie.

Du Bruyn, JT 1986. Die Groot Trek. In: Cameron, T (red). Nuwe geskiedenis van Suid-Afrika en woord en beeld. Kaapstad: Human en Rousseau. 127-139.

Giliomee, H 2003. The Afrikaners. Biography of a people. Kaapstad: Tafelberg.

Grobler, J 2007. Uitdaging en antwoord. 'n Vars perspektief op die evolusie van die Afrikaners. Brooklyn: Grourie.

Liebenberg, BJ 1977. Andries Pretorius in Natal. Pretoria: Academica.

Nederduitse Gereformeerde Kerk 2013. Die Kerkorde. Sl:sn. 
NGK in Zuid-Afrika (ZA) 1858. Handelinge van de Algemeene Synode der NG Kerk 1837. In: Handelinge 1824-1847. Kaapstad: Van de Sandt De Villiers en kie.

Preller, G 1920. Voortrekkermense II. 'n Drietal oorspronklike dokumente oor die Voortrek. Kaapstad: De Nationale Pers.

Sadler, THN 1979. Die kerklike tughandeling. Pretoria: NG Kerkboekhandel.

Strauss, PJ 2001. Nogeens: die agtergrond, inhoud en implikasies van die Gelofte van 1838. HTS 57/3 en 4, 814-834.

Strauss, PJ 2011. Nogeens: watter kerk vergesel die Groot Trek? Acta Theologica 31/2, 264-277.

Strauss, PJ 2015. Gereformeerdes onder die Suiderkruis 1652-2011. Bloemfontein: Sun Media.

Thom, HB 1965. Die lewe van Gert Maritz. Elsiesrivier: Nasou.

Van der Watt, PB 1973. Die Loedolffsaak en die Nederduitse Gereformeerde Kerk 1862-1962. Kaapstad: Tafelberg.

Van der Watt, PB 1977. Die Nederduitse Gereformeerde Kerk 1834-1866. Pretoria: NG Kerkboekhandel.

Visagie, J 2012. Oorsake van die Groot Trek na die binneland. In Pretorius, $\mathrm{F}$ (red), Geskiedenis van Suid-Afrika in voortye tot vandag. Kaapstad: Tafelberg, 117-128.

Visagie, J 2012. Uittog en vestiging van die Voortrekkers in die binneland. In Pretorius, $\mathrm{F}$ (red), Geskiedenis van Suid-Afrika in voortye tot vandag. Kaapstad: Tafelberg, 131-150. 